spite calls for the rationalisation of government from industry, there is very little information available on the actual demand for public services from industry. This matches the lack of demand-driven approaches to devising ICT applications to be found in public administration. Common approaches focus either on socalled "life situations" (such as applying for a passport) or on "high frequency transactions", which are largely standardised and thus amenable to automation. Schmutzer concluded his presentation with an outlook on future developments. He foresaw a rapid increase of applications for electronic transactions, a trend towards service provision by public administrations and a growing number of applications for highly standardised data exchange, such as tax and customs. On the other hand, he felt that progress would be slow in the development of individualised services, such as plant licensing by industry.

\section{Closing plenary session}

The final point in the conference was a plenary presentation by Professor Juliet Webster (Trinity College, Ireland): "The value of women and men: gendering knowledge and skills in the Information Society". She picked up one of the main threads of the SOWING project by discussing questions of social exclusion against the background of gender differences.

She was concerned with the organisation of work and with the skills and forms of knowledge which are becoming most prevalent in low-grade service work in the Information Society. Her focus was specifically on two service sectors - retailing and retail financial services. She examined developments in the two sectors and the major forms of expertise or skill which characterise routine work. She emphazised particularly employers' desire for employees with "customer services skills" and "interpersonal skills" and examined how these skills are developed and conferred in workplaces, and the training which employers engage in. Juliet Webster addressed the question of whether these skills, once acquired by employees, are gendered, and if so, in what ways. Do new forms of skill, if they exist, enable their holders to move into what is often described as "knowledge work", and so in the long run improve their employability?

\section{ANKÜNDIGUNGEN}

\section{Konferenzen/Workshops/Seminare}

\author{
Den Kopf in den Sand? \\ Über Gefahrenerkennung in \\ der wissenschaftlich- \\ technischen Zivilisation
}

Mülheim an der Ruhr, 12. - 14. Januar 2001

Für Lebewesen und Artgemeinschaften ist die rechtzeitige Erkennung von Gefahren mitentscheidend für ihr Überleben im „Kampf ums Dasein". Deshalb haben sie in der Evolution wirkungsvolle Verfahren zur Gefahrenerkennung entwickelt.

Unsere wissenschaftlich-technische Zivilisation hat nun aber neuartige Groß-Risiken mit sich gebracht, für deren Erkennung der Mensch weder durch seine natürlichen Sinnesorgane noch durch bewährte gesellschaftliche Verfahren gerüstet ist. Daher rührt in nicht geringem Maße die gegenwärtige ökologische Bedrohung unsere Existenz. Die bisher im Zusammenwirken von Umweltwissenschaften, Politik und Justiz geübte Praxis zur Identifizierung von Gefahren ist schon deshalb unzureichend, weil man Gefahrenerkennung noch nicht einmal als erkenntnistheoretisches, geschweige denn als wissenschaftsorganisatorisches und politisches Problem hinreichend erfasst und diskutiert hat. Dies zeigt die Analyse von Fallbeispielen sehr deutlich. Eines der Hauptprobleme ist die Asymmetrie zwischen "Chancen“ und „Risiken“ mit den daraus resultierenden Interessenkonflikten. Die Chancen sind klar erkennbar, über kurze Kausalketten kurzfristig erreichbar und marktförmig privatisierbar. Hier liegen die ökonomischen Interessen und die kommerzielle Macht. Die „Risiken“ kommen meist über unüberschaubare Wirkungen und Nebenwirkungen durch die Hintertür und betreffen andere als die Nutznießer und Verursacher, oft erst künftige Generationen. Die an den Chancen Interessierten aber wollen die Risiken nicht sehen und stecken den Kopf in den Sand.

Die Politik - also die Gesetzgebung - und die Rechtsprechung stehen vor neuartigen 
Problemen, die belastet sind durch tiefliegende Missverständnisse zwischen (gutachterlicher) Wissenschaft und der Justiz.

Die Tagung wird von der Evangelischen Akademie Mülheim an der Ruhr in Zusammenarbeit mit dem Wuppertal-Institut veranstaltet.

Die Vortragenden und ihre Themen sind:

Prof. Dr. Günter Tembrock, Berlin: „Wie erkennen Lebewesen Gefahren?“

Dr. Leberecht v. Klitzing, Lübeck: „Welche Gefahren birgt Elektrosmog?"

Dr. Andreas Gies, Umweltbundesamt, Berlin: „Spermakrise“: Droht der Verlust männlicher Fertilität?“”

Prof. Dr. Erich Schöndorf, Frankfurt a.M.: „Der Holzschutzmittel-Prozess. An der Schnittstelle zwischen Recht und Wissenschaft"

Prof. Dr. Martin Schulte, Dresden: „Zum Umgang mit Wissen, Nicht-Wissen und unsichtbarem Wissen im Bereich des Rechts"

Prof. Dr. Michael Drieschner, Bochum: „Nicht Fakten, sondern Möglichkeiten: Was heißt es, Gefahren zu erkennen?"

Dr. Hans-Jochen Luhmann, Wuppertal Institut: „Von der Verdrängung zur Erkenntnis. Defizite in der Organisation der Sorgfalt bei der Gefahrenerkennung“"

Außerdem finden Gruppengespräche mit den Referenten oder geladenen Gästen zum Thema „Risiko und Gefahr“ sowie „Konsequenzen für die Politik" statt.

\section{Kontakt}

Evangelische Akademie Mülheim an der Ruhr

Dr. Hans-Jürgen Fischbeck

D-45479 Mülheim an der Ruhr

Tel.: + 49 (0) 208 - 59906-0

Fax: + 49 (0) 208 - 59906-600

E-Mail: hans-juergen.fischbeck@ev-akademiemuelheim.de

Tagungssekretariat: Petra Büssemeiner

Tel.: + 49 (0) 208 - 59906-543

Montag bis Freitag 8.00 bis $13.00 \mathrm{Uhr}$

Fax für Gäste: + 49 (0) 208 - 59906-686

\section{Fourth annual aeronautics day "2001 - Preparing for the global challenges"}

Hamburg, Germany, 29 - 31 January, 2001

European Research Commissioner Philippe Busquin is expected to attend the fourth annual aeronautics day "2001 - Preparing for the global challenges" taking place in Hamburg on 29 to 31 January, along with the chairmen of the Research Council and of the European Parliament Committee for Research.

The event is intended to address the technological and industrial development of the European aeronautics sector, taking in perspectives from politics, industry and the research community, in response to Europe's social needs and expectations. Indepth thematic presentations of the technological achievements and ongoing activities of collaborative aeronautical $R \& D$ will be available especially under the "New perspectives in aeronautics" Key Action of the EU's Fifth Framework Programme (FP5).

Results of European collaborative projects on aeronautics research will be presented in an exhibition, whilst parallel sessions on the following topics will be held:

- Development cost and time to market;

- $\quad$ Aircraft efficiency;

- Environmental friendliness of aircraft;

- Aircraft operational capability and safety;

- Air traffic management and control;

- National and international research collaboration in aeronautics;

- SME industry in the aeronautical supply chain.

(Source: CORDIS focus)

\section{A more detailed programme as well as reg- istration forms will soon be available at the following Web address:}

http://europa.eu.int/comm/research/growth/gcc/inaction-aero02.html 


\section{Keeping The Lights On: Elec- tric Tradition or Innovation?}

\author{
London, UK, 14 - 15 March, 2001
}

Liberalization and technical innovation are overturning guiding premises that shaped traditional electricity systems for a century. Traditional and innovative technologies, finances and institutions are not readily compatible. Yet they now have to co-exist, under conditions far from ideal for either. Will tradition hold back innovation? Will innovation undermine tradition? As risks and responsibilities change, who will be keeping the lights on, for whom, and how?

As yet these far-reaching issues are only dimly visible, beyond the immediate turmoil of power cuts and price spikes, mergers and acquisitions, regulatory upheavals, international rivalry and political furore. Nevertheless the intensifying clash between tradition and innovation will determine the future role and nature of electricity in human society.

The Royal Institute of International Affairs is proud to be organizing this groundbreaking conference. The agenda is being developed by Walt Patterson, senior research fellow in the Energy and Environmental Programme, at Chatham House, and author of "Transforming Electricity: The Coming Generation of Change" (1999).

Topics for discussion will include:

- Electricity and innovative electricity technologies and their system implications

- Electricity institutions - tradition and innovation for governments and companies: regulation and business

- Electricity finances - traditional and innovative approaches

- Keeping the lights on - can tradition and innovation be reconciled?

Michel Chamia, immediate past President of CIGRE, Roger Gale, Chief Executive Officer, PHB Hagler Bailly and Dr Rajendra Pachauri, Director, Tata Energy Research Institute have already confirmed that they will be giving keynote addresses. They will be joined by an international gathering of senior people from government, industry, academia and nongovernmental organizations, to consider the global ramifications of this issue, its significance for economic, social and environmental policy, and its wide-ranging political implications.

\section{Registration}

The Royal Institute of International Affairs

Ms Catherine O'Keeffe

Acting Head, Conference Unit

Chatham House

10 St James's Square

London SW1Y 4LE, UK

Fax: + 44 (0) 2073212045

Website: http://www.riia.org

\section{Call for papers}

\section{RTD benchmarking conference}

\author{
Brussels, Belgium, 15 - 16 March, 2001
}

A call for papers has been issued by DG Research, organisers of a conference looking at the contribution of European socio-economic research to the benchmarking of RTD (research and technological development) policies in Europe, to be held in Brussels on 15 and 16 March 2001.

The need for benchmarking of RTD policies draws instructions from Europe's research ministers in June to benchmark Member State's RTD policies in the following areas:

- human resources;

- public and private investment;

- $\quad$ scientific and technological productivity;

- impact on economic competitiveness and employment.

(Source: CORDIS focus)

\section{For further information, please contact:}

Nikos Kastrinos

DG RTD

European Commission

Fax: + 32-2-2958865

E-mail: nikolaos.kastrinos@cec.eu.int

Internet: http://www.cordis.lu/improving 


\section{Biotechnology ethics and pub- lic perceptions of biotechnol- ogy}

Oxford, UK, 16 - 25 March, 2001

An EU advanced workshop on "biotechnology ethics and public perceptions of biotechnology" will be held next year from 16 to 25 March 2001 at Oxford University in the UK.

This intensive and interactive workshop covers: Moral theories and philosophy from concept to practice; Importance of ethics for science and engineering; Regulations, laws, codes and ethics and their relationships; Public perceptions of biotechnology, linking attitudes to behaviour; Communication approaches and their effectiveness; How the media work; Communication strategies used by companies, academia and NGOs.

The cost, including full board and course materials, is €1000. Participants from less favoured regions in Europe can apply for a full grant, while 12 grants of $€ 500$ are available for other EU participants. The course, which is supported by the European Commission's Quality of Life programme, is for PhD students, lecturers, postdoctoral fellows and industrial researchers in biotechnology.

The course is credited as part of the European Doctorate in Biotechnology (EDBT) study programme. A limited number of places is available so early application is advisable. Applicants should send their curriculum vitae and a letter briefly explaining their interests in the course (and if applicable a request for a grant) before 1 January 2001 to the address below.

(Source: CORDIS focus)

\section{For further information, please contact:}

Dr. David J. Bennett

Oude Delft 60

NL-2611 CD Delft

Tel.: + 31-15-2127800

Fax: + 31-15-2127111

E-mail: efb.cbc@stm.tudelft.nl http://www.cordis.lu/life/src/event120301.htm http://efbweb.org/ppb

》

\section{Renewable energy in maritime island climates}

\author{
Belfast, Northern Ireland, 3 - 4 May, 2001
}

The European Commission will participate in a conference on renewable energy in maritime island climates in Belfast, Northern Ireland, on 3 and 4 May 2001.

The Centre for Sustainable Technologies, the University of Ulster and the Solar Energy Society are organising the event and inviting abstracts on wind, biomass, solar thermal and photovoltaics, hydro, wave, and tidal power, energy conscious building and materials, and integration of renewables and policy.

(Source: CORDIS focus)

For further information, please contact:

\author{
ISLENET \\ V. Argyraki \\ 200 rue Engeland/Engelandstraat, B-1180 Brussels \\ Tel.: + 32-2-3750281 \\ E-mail: vargyraki@skynet.be \\ E-mail: remic@ulst.ac.uk \\ Internet: http://www.engj.ulst.ac.uk/REMIC
}

\section{Eco-Informa 2001: Environ- mental risks and the global community - strategies for meeting the challenges}

Chicago, USA, 14 - 18 May, 2001

A specialist conference for European and US scientists in the field of environment and environmental information will be held from 14 to 18 May 2001 in Chicago. The meeting is being organised by the US Department of Energy Centre for Risk Excellence, Argonne National Laboratory and the Eco-Informa Foundation. The central focus of Eco-Informa 2001 is on developing solutions for the global community to:

- meet freshwater demands of increasing populations and expanding economies;

- $\quad$ supply adequate, safe and nutritious food; 
- provide economically reliable and environmentally sustainable energy;

- preserve diverse natural resources and mitigate environmental contamination.

Key speakers are invited from Europe, North and South America, Africa, Asia, Australia and New Zealand.

(Source: CORDIS focus)

\author{
For more information please consult the \\ following website: \\ http://eco-informa.ead.anl.gov/ \\ or contact: \\ Prof Walter Leal Filho \\ TuTech \\ Schellerdamm 4, D-21079 Hamburg \\ Tel.: + 49 (0) 40 - 76618059 \\ Fax: + 49 (0) 40 - 76618048 \\ E-mail: leal@tutech.de
}

》

\section{Benchmarking best practice in research administration}

Stockholm, Sweden, 15 - 16 June, 2001

The meeting will be held by the European Association for Research Managers and Administrators (EARMA).

So far, several topics under this heading have been identified for further consideration (with concurrent sessions organised in several tracks):

- $\quad$ research management and administration to greater professional competence;

- equal opportunity in science - how to create a research environment feasible for both sexes;

- towards a European patent;

- follow-up on the Fifth Framework Programme;

- full cost versus additional cost - new methods of accounting.

In anticipation of the enlargement of the European Union, EARMA is also developing ideas to involve colleagues from preaccession countries in its activities.
The organisers plan to offer participants a "pre-conference", starting in Helsinki, Finland. Part of the programme will be carried out during the boat trip from Helsinki to Stockholm. The organisers are inviting participants' suggestions for topics to be addressed during the conference.

(Source: CORDIS focus)

\section{For more information please contact:}

Katarina Bjelke

Grants and Contracts manager

Grants Office

Karolinska Institute

Nobels vag5, S-171 77 Stockholm

Tel.: + 46-7286028

Fax: + 46-8318406

E-mail: katarina.bjelke@admin.ki.se

First announcement and call for papers

\section{Open Meeting of the Human Dimensions of Global Environmental Change Research Community}

Rio de Janeiro, Brazil, 6 - 8 October 2001

Following three successful international meetings held at Duke University (USA) in 1995, IIASA (Austria) in 1997, and Shonan Village (Japan) in 1999, the research community will meet in Brazil in 2001. Information about the previous meetings can be found on http://www.iges.or.jp. The community is involved in research on the causes and consequences of, and responses to, global environmental change. An important goal of the meeting is to continue the exchange of information about ongoing research and the establishment and strengthening of research networks. The meeting will also seek to evaluate the progress made during the past 10 years in nurturing high quality research in this area and in related capacity building endeavours.

Particular emphasis will be placed on research reports that include a regional or "placebased" perspective and that make a linkage 
between natural and social sciences, as well as between local, regional and global scales.

Plenary themes of the meeting will address the challenges of integration in human dimensions research - across disciplines, across hemispheres, and across the science/ policy interface. They will also address issues of central importance to both the developed and the developing world - "urban sustainability", "vulnerability", and "poverty and the environment". One plenary talk will discuss the climate change issue in the post-Kyoto era and the implications for human dimensions research.

In addition to plenary talks, there will be a large number of sessions devoted to the presentation of research on the human dimensions of global environmental change, including topics such as land use and land cover change, energy, environmental security, industrial transformation, sustainable development, integrated assessment, population and the environment, environment and health, attitudes and behaviour, consumption, trade and the environment, environmental governance, environmental and ecological economics and the science/policy interface.

The International Scientific Planning Committee welcomes the submission of abstracts, as well as proposals for sessions. Selection of the abstracts and session proposals will be based on scientific quality and the need to develop a coherent and balanced meeting agenda. Those submitting individual abstracts will be asked to indicate whether they wish to present a paper or a poster (or either one). Those submitting proposals for entire panels will be asked to name a chair, four papergivers, and one discussant - each paper should have its own abstract. The ISPC will also consider a small number of proposals for sessions in a round-table format. If abstracts are accepted, the ISPC will welcome submission of a full paper for publication on a CD to be distributed shortly after the meeting.

The Committee seeks the participation of researchers from a broad range of disciplines. We especially encourage researchers from developing countries and countries with economies in transition, as well as young researchers from all over the world, to submit proposals. For these categories of researchers, efforts will be made to provide financial support for participants whose abstracts are selected for presentation at the meeting. Participants from other communities, such as NGOs, business and government, will also be welcome.

The deadline for submission of abstracts and session proposals is March 29, 2001.

Information about the meeting, including instructions for the submission of abstracts, will be available on the following website: http://sedac.ciesin.org/openmeeting.

Enquiries can be addressed to open.meeting@ciesin.org.

First Announcement and Call for Papers

\section{Innovations for an e-Society. Challenges for Technology Assessment}

Berlin, Germany, 17 - 20 October 2001

Information on this congress, organized by ITAS and VDI/VDE-IT Information Technologies $\mathrm{GmbH}$, Germany with the support of the Federal Ministry for Education and Research $(B M B F)$ can be found in the ITAS News Section. 